УДК 619: 615.36: 616.379-008.64

(C) 2017

Ковпак В. В., кандидат ветеринарних наук, Ковпак O. C., аспірант

(науковий керівник - доктор ветеринарних наук А. Й. Мазуркевич)

Національний університет біоресурсів і природокористування України

\title{
ВПЛИВ ТРАНСПЛАНТАЦЇ̈ КУЛЬТУР КЛІТИН НА СТАН ОСТРІВКОВОГО АПАРАТУ ПІДШЛУНКОВОЇ ЗАЛОЗИ ТА РІВЕНЬ ГЛЮКОЗИ У КРОВІ ЗА ЕКСПЕРИМЕНТАЛЬНОГО ЦУКРОВОГО ДІАБЕТУ У ТВАРИН
}

\section{Рецензент - доктор ветеринарних наук, професор М. О. Малюк}

У статті описано вплив різних видів культур клітин (підшлункової залози, кісткового мозку та жирової тканини) на перебіг експериментального иукрового діабету у щурів. Досліджено, щуо оптимальним методом введення клітинного матеріалу, $\epsilon$ трансплантащія його під капсулу підшлункової залози. Під час дослідження стану острівкового апарату за введення різних видів культур клітин на фоні иукрового діабету виявили, шчо всі вони володіють позитивним терапевтичним ефектом під час лікування вказаної патології. Отримані дані підтверджуються збільшенням загального об' 'му острівкової тканини у тварин-реципієнтів (у порівнянні з контрольною групою), шьо у свою чергу призводить до зниження рівня глюкози у сироватці крові.

Ключові слова: культура клітин, иукровий діабет, кістковий мозок, жирова тканина, підшлункова залоза, острівці Лангерганса.

Постановка проблеми. Основою розвитку інсулінзалежного цукрового діабету $є$ зменшення кількості $\beta$-клітин підшлункової залози, що призводить до зниження рівня інсуліну у крові. Тому важливим питанням лікування цукрового діабету $\epsilon$ відновлення острівців Лангерганса. Трансплантація культури клітин є одним 3 перспективних методів лікування цукрового діабету, що сприяє відновленню острівкового апарату підшлункової залози.

Аналіз основних досліджень і публікацій, у яких започатковано розв'язання проблеми. Цукровий діабет - це група метаболічних захворювань, що характеризуються підвищеним вмістом глюкози в крові (гіперглікемія) в результаті дефектів секреції інсуліну, дії інсуліну або обох факторів. Інсулін - це гормон що виробляється $\beta$-клітинами підшлункової залози, який необхідний для використання глюкози, як джерела енергії, клітинами. При цукровому діабеті 1 типу організм не виробляє інсулін, що призводить до необхідності щоденних його ін'єкцій $[2,3,5,15]$. Проте тривале використання замісної терапії та гіпоглікемічних препаратів може призвести до інсулінорезистентності, а також не попереджує розвитку макро- і мікроваскулярних ускладнень $[7,8,18]$.

Тому увага багатьох науковців спрямована на пошук методів лікування цукрового діабету шляхом відновлення острівців Лангерганса. Клітинні технології $\epsilon$ перспективним напрямком лікування цукрового діабету, що спрямований на регенерацію острівкового апарату підшлункової залози $[1,6,11,16]$.

Мета дослідження: дослідити вплив трансплантації культур клітин кісткового мозку, жирової тканини та підшлункової залози на стан острівкового апарату підшлункової залози та рівень глюкози у крові за експериментального цукрового діабету у тварин.

Завдання дослідження: отримати культури клітин кісткового мозку, жирової тканини та підшлункової залози; сформувати експериментальний алоксановий цукровий діабет у щурів; визначити оптимальний метод введення клітинного матеріалу; провести морфометричне дослідження стану острівкового апарату за трансплантації культур клітин на фоні цукрового діабету; проаналізувати отримані результати.

Матеріали та методи дослідження. В дослідах використовували клінічно здорових тварин (30 самців білих нелінійних щурів масою тіла 200-250 г, віком 4-5 місяців; 9 білих нелінійних щуренят 12-денного віку). Експерименти на тваринах були проведені з дотриманням вимог Закону України «Про захист тварин від жорстокого поводження» (ст. 230 від 2006 року) та Положення про утримання та використання піддослідних тварин у віварії та клініці НАУ, розглянутого та затвердженого ректором НАУ 20.05.2001 p.

У дослідженні використовували культури клітин кісткового мозку, підшлункової залози (які отримували 3 кісткового мозку трубчастих кісток та підшлункової залози щуренят віком 12 


\section{ВЕТЕРИНАРНА МЕДИЦИНА}

діб) і жирової тканини (отримували від щурів віком 4-5 місяців). Культивування клітин здійснювали за стандартною методикою у $\mathrm{CO}_{2}$ інкубаторі [10].

Експериментальну модель цукрового діабету ми відтворювали шляхом одноразового підшкірного введення алоксану моногідрату (Sigma, США) в дозі 150 мг/кг у вигляді $5 \%$ розчину в цитратному буфері, pH 4,5 після попередньої 24-годинної депривації їжі (за вільного доступу до води). Для зменшення загибелі тварин внаслідок гіпоглікемічного шоку після введення «Алоксану», вони протягом 24 годин після індукції діабету замість води отримували 5 \% розчин глюкози [4].

Для дослідження міграційної здатності клітин тваринам-реципієнтам 3 алоксановим цукровим діабетом трансплантували 2 млн (в об'ємі 50 мкл) клітин культури кісткового мозку двома шляхами: внутрішньовенно та під капсулу підшлункової залози (у якості контролю проводили аналогічні введення фосфатно-буферного розчину). Культуру попередньо обробляли вітальним ядерним барвником «Hoechst 33258» (Sigma, США) за стандартною методикою (після мічення клітини флуоресціюють яскраво зеленим кольором) [14]. На 8-му добу тварин виводили 3 досліду та відбирали зразки підшлункової залози. Виявлення клітин проводили на кріозрізах виготовлених за стандартною методикою $[13,9]$. Зразки досліджували під флуоресцентним мікроскопом «Leica DMR» (Німеччина).

Відбір проб тканин для гістологічних досліджень проводили на 50-ту добу експерименту (контрольна група та дослідна - 30-та доба після трансплантації клітин). Після відбору зразків їх фіксували в $10 \%$ розчині нейтрального формаліну протягом 24 годин, далі тканини зневоднювали та заливали в парафін за стандартними методиками [17]. Зрізи завтовшки 5 нк виготовляли за допомогою ротаційного мікротома НM 320 E (MICROM, Німеччина) та системи переносу зрізів (STS, MICROM, Німеччина). Для дослідження мікроструктури тканин зрізи фарбували гематоксиліном та еозином [12], після чого препарати піддавали світловій мікроскопії. Оцінку й аналіз препаратів здійснювали за допомогою мікроскопа «Leica DMR» (Німеччина).

Стан підшлункової залози у тварин досліджували на фоні цукрового діабету (50-та доба експерименту) та на 30-ту добу після трансплантації культур клітин. Морфометричне дослідження стану острівкового апарату проводили на забарвлених препаратах. Підраховували загальну кількість ост-

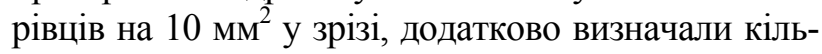
кість клітинних ядер у острівцях. Дослідження проводили на 3-х несерійних зрізах, зроблених із відступом 0,5 мм один від одного (відстань більша ніж розмір одного острівця).

Результати власних досліджень. Однією is біологічних властивостей стовбурових клітин $є$ їх здатність міграції в зону патологічного процесу. Відомо, що в разі трансплантації МСК в організм дорослої тварини без експериментальних пошкоджень до 25 \% донорського матеріалу виявляють у червоному кістковому мозку [20]. Особливий інтерес представляє міграція стовбурових клітин в організмі, що має зону пошкодження. В роботі $\mathrm{Wu} 3$ колегами показано, що ендогенні МСК мігрують в зону відторгнення алогенного трансплантату [19]. Вважають, шо міграція стовбурових клітин у зону патологічного процесу обумовлена цитокінами та хемокінами запалення. Водночас механізм міграції в зону пошкодження вивчений недостатньо, тому одним із наших завдань було дослідити міграційну здатність культури клітин кісткового мозку залежно від способу їх уведення в організм тварини-реципієнта.
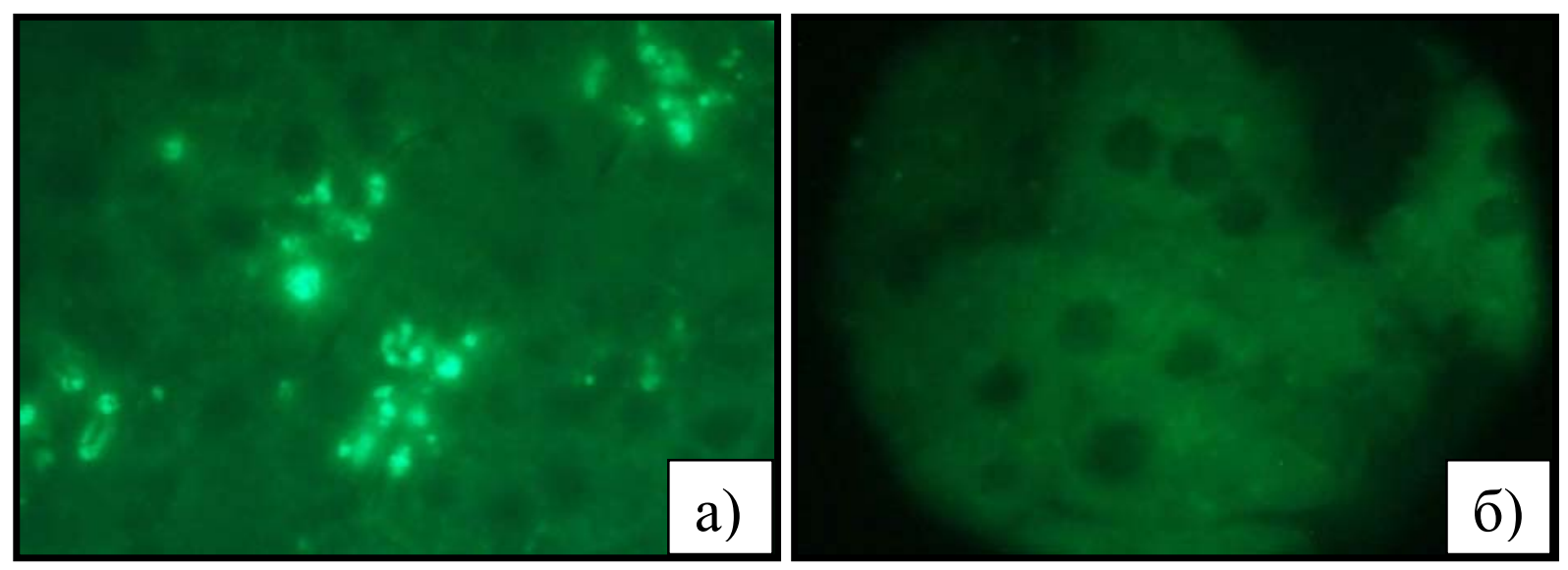

Рис. 1. Виявлення у підилунковій залозі клітин мічених Ноесhst: a) трансплантація під капсулу; б) контроль. Кріозрізи, флуоресцентна мікроскопія, ЗбЧ1000. 


\section{ВЕТЕРИНАРНА МЕДИЦИНА}

Зміни острівкового апарату підчлункової залози за трансплантації культур клітин на фоні алоксанового цукрового діабету

\begin{tabular}{|l|c|c|}
\hline \multicolumn{1}{|c|}{ Група тварин } & $\begin{array}{c}\text { Середня кількість острівців } \\
\text { Лангерганса }\end{array}$ & $\begin{array}{c}\text { Середня кількість клітин } \\
\text { у острівці }\end{array}$ \\
\hline Інтактні тварини & $9,7 \pm 1,0$ & $100,0 \pm 14,9$ \\
\hline Контрольна & $9,7 \pm 1,3$ & $62,5 \pm 12,4$ \\
\hline За введення КККМ & $14,7 \pm 1,4^{*}$ & $111,0 \pm 13,9^{*}$ \\
\hline За введення ККПЗ & $17,7 \pm 1,9^{*}$ & $78,3 \pm 14,0$ \\
\hline За введення ККЖТ & $10,7 \pm 0,8$ & $69,5 \pm 10,3$ \\
\hline
\end{tabular}

Примітка: *p<0,05; (показники 50-ї доби алоксанового цукрового діабету порівнювали 3 показниками інтактних тварин, показники після трансплантації ККПЗ, КККМ та ККЖТ за ЦД порівнювали 3 показниками 50-ї доби (контроль).

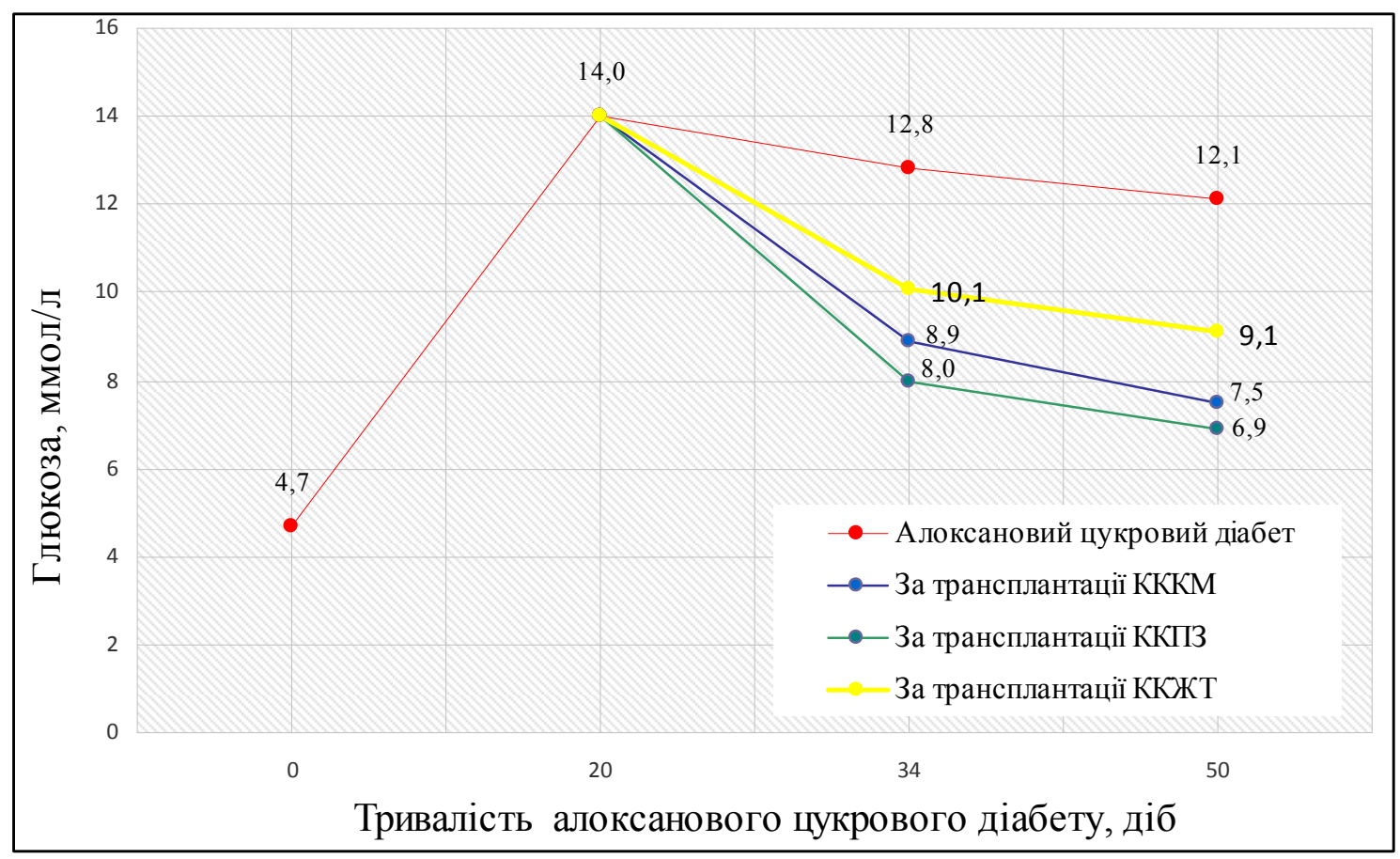

Рис. 2. Рівень глюкози у крові щурів за цукрового діабету на фоні введення культур клітин, $n=5(M \pm m)$

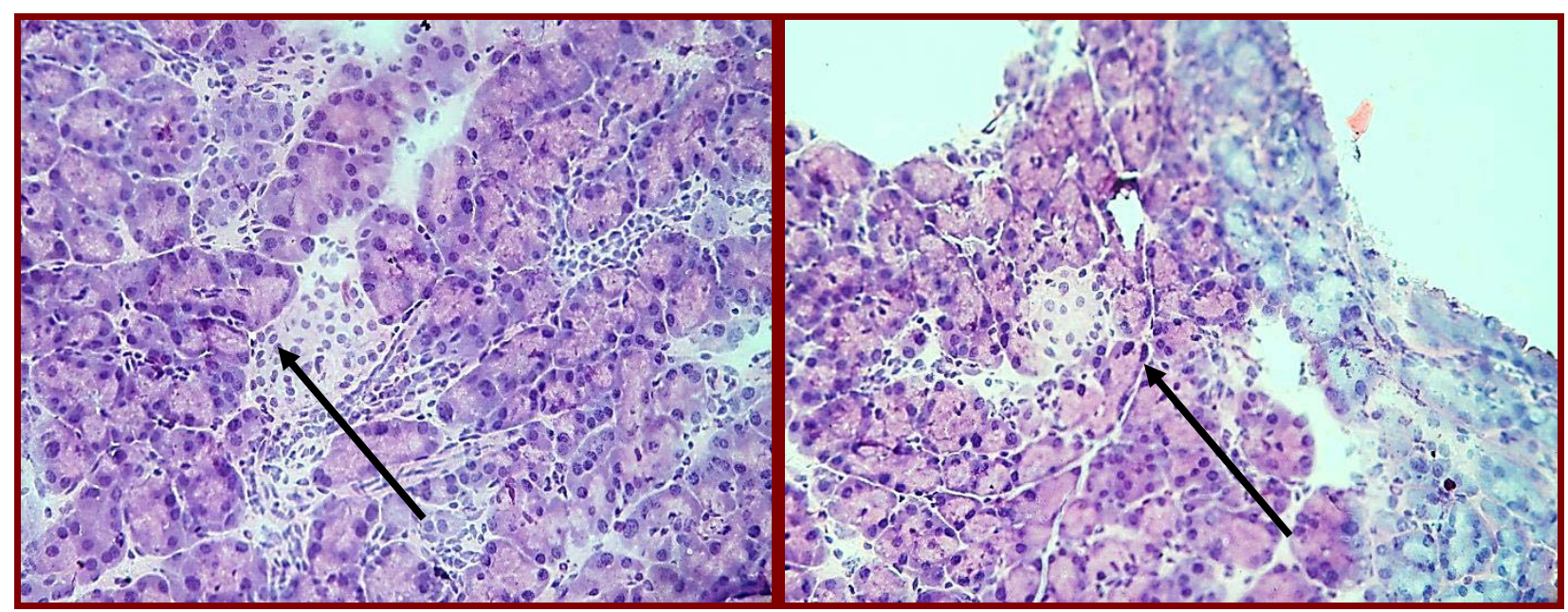

Рис. 3. Поява нових острівців Лангерганса у підилунковій залозі цурів з експериментальним цукровим діабетом за алогенної трансплантації культури клітин підилункової залози 
Введення клітин виконували 2-ма шляхами: внутрішньовенно та під капсулу підшлункової залози. Результати оцінювали шляхом виявлення мічених клітин у кріозрізах підшлункової залози (рис. 1).

У разі місцевого введення клітин культури підшлункової залози тваринам з експериментально сформованих цукровим діабетом на 8-му добу спостерігали їх дифузне розміщення в тканині підшлункової залози (рис. 1a). Отримані дані свідчать не лише про збереження життєздатності клітин після введення протягом тривалого часу, a i про їх міграцію у товщу пошкодженого органа. За внутрішньовенного введення клітин мічених Hoechst виявляли поодинокі сигнали, що свідчить про незначну кількість клітин, які досягли підшлункової залози. Тому для подальших досліджень проводили трансплантацію культур клітин під капсулу підшлункової залози.

Наступним кроком у наших дослідженнях було порівняння морфометричних даних підшлункової залози щурів за алоксанового цукрового діабету без лікування (контрольна група) та за трансплантації різних видів культур клітин.

Варто зазначити, що за макроскопічної оцінки підшлункової залози інтактної, контрольної та дослідних груп тварин відмінностей не відмічали.

Під час гістологічного дослідження підшлункової залози інтактних щурів було встановлено, що середня кількість острівців на 10 мм $^{2}$ зрізу товщиною 5 мкм становить $9,7 \pm 1,0$, а середня кількість клітин в острівці Лангерганса $100,0 \pm 14,9$ (див. табл.).

Під час дослідження тканини підшлункової залози щурів контрольної групи (яким трансплантацію не виконували) ми не виявили змін кількості острівців у порівнянні з інтактними тваринами, проте середня кількість клітин у острівцях зменшилася у 1,6 рази.

Проте під час дослідження рівня глюкози у крові на 50-ту добу експерименту ми відмічали іiі незначне достовірне зниження (рис. 2). Отримані дані свідчать про те, що у тварин з 20-ї до 50-ї доби експерименту може відбуватися перебудова клітинного складу в острівцях підшлункової залози, що залишилися після дії «Алоксану», зі збільшенням питомого об'єму $\beta$-клітин за рахунок прискорення проліферації острівкових клітин із диференціюванням їх у $\beta$-клітини, але загальний об'єм острівкової тканини залишається незмінним та не спостерігається неогенез острівців.

Під час гістологічного дослідження тканини підшлункової залози тварин групи, яким викону- вали трансплантацію культури клітин підшлункової залози, відмічали збільшення середньої кількості острівців на одиницю площі, у порівнянні із тваринами контрольної групи. На 50-ту добу експерименту це збільшення становило 1,8 рази $(\mathrm{p}<0,05)$. При цьому їхній розмір сильно варіював.

Отримані результати свідчать про те, що після трансплантації культури клітин підшлункової залози відбувається значне прискорення проліферації клітин у острівцях, що існували до трансплантації, що у свою чергу призводить до зростання їх площі, і появи нових острівців малого розміру (рис. 3, стрілка). Збільшення існуючих острівців та поява нових призводить до відчутного і достовірного зростання питомого об'єму острівкової тканини.

Під час гістологічного дослідження тканини підшлункової залози групи тварин, яким виконували трансплантацію культури клітин кісткового мозку, було виявлено як збільшення кількості острівців на одиницю площі, у порівнянні із тваринами контрольної групи, так і збільшення їхнього середнього розміру (середня кількість острівців на $10 \mathrm{mм}^{2}$ зрізу товщиною 5 мкм збільшилась на 1,5 рази). Зустрічалися як дрібні острівці, так і великі, на 50-ту добу експерименту деякі з них містили більше 170 клітин. Дані морфологічного дослідження показують, що в разі трансплантації культури клітин кісткового мозку спостерігається більш виразне прискорення проліферації клітин, хоча кількість острівців у порівнянні з групою тварин, де здійснювали трансплантації культури клітин підшлункової залози, нижча, але розміри деяких острівців набагато збільшуються. Тому питомий об'єм острівкової тканини і кількість інсулін-позитивних клітин на одиницю площі значно збільшуються.

Отримані дані свідчать, що введення культури клітин жирової тканини також призводить до посилення неогенезу острівців, але ці острівці мають невеликий розмір (до 50 клітин). Збільшення питомого об'єму острівкової тканини на одиницю площі було найнижчим серед усіх застосованих методів трансплантації.

Висновок. Найбільш ефективним методом трансплантації культур клітини за цукрового діабету у тварин $\epsilon$ введення під капсулу підшлункової залози тварин-реципієнтів.

Після трансплантації культури клітин підшлункової залози відбувається збільшення острівкової тканини в першу чергу шляхом неогенезу острівців, а також за рахунок прискорення регенерації клітин у раніше сформованій острівковій тканині. 


\section{ВЕТЕРИНАРНА МЕДИЦИНА}

Трансплантація культури клітин кісткового мозку призводить до збільшення острівкової тканини в більшій мірі за рахунок регенерації шляхом посилення проліферативної активності клітин острівців.

Трансплантація культури клітин жирової тканини стимулює неогенез острівців Лангерганса у

\section{БІБЛІОГРАФІЯ:}

1. Алиев M. А. Трансплантация культур островковых клеток поджелудочной железы больным сахарным диабетом / [Алиев М. А., Исмагилов Р. 3., Рысбеков М. М. и др.] // Трансплантологія. -2000 . - Т.1, №1. - С. 147-151.

2. Дедов И. И. Болезни органов эндокринной системы / И. И. Дедов. - М. : Медицина, 2000. С. 149-252.

3. Дедов И. И. Сахарный диабет: ретинопатия, нефропатия / И. И. Дедов, М. В. Шестопалова, Т. М. Миленькая. - М. : Медицина, 2001. $176 \mathrm{c}$.

4. Жилюк B. I. Аналіз морфометричних та ультраструктурних характеристик гемомікроциркуляторного русла гіпокампу щурів 3 алоксановим діабетом за умов введення цитиколіну / B. I. Жилюк, В. Й. Мамчур, Н. С. Петрук, А. Е. Лєвих // Scientific Journal «ScienceRise». 2015. - №7/4 (12). - С. 53-59.

5. Зорин А. И. Сахарный диабет у собак и кошек / А. И. Зорин // РВЖ МДЖ. - 2005. - №2. - C. 44-47.

6. Зорин А. И. Сахарный диабет у собак и кошек / А. И. Зорин // РВЖ МДЖ. - 2005. - №2. - C. 44-47.

7. Ковальська I. О. Цукровий діабет та трансплантація / I. О. Ковальська // Трансплантологія. -2000. - Т.1, №1. - С. 140-142.

8. Комісаренко I. В. Ендокринологія / [Комісаренко І. В., Боднар П. М., Комісаренко Ю. І. та ін.]. - К. : «Здоров'я», 2003. - 512 с.

9. Луnпа X. Основы гистохимии / Х. Луппа ; [пер. с немецкого И. Б. Бухвалова, Е. Д. Вальтер]. - М. : Мир, 1980. - 343 с.

10. Мазуркевич А. Й. Клітинні технології у ветеринарній медицині : навч. посібник для студ. вищ. навч. закладів / А. Й. Мазуркевич, В. В. Ковпак, В. Б. Данілов. - К. : КОМПРИНТ. - 2014. $132 \mathrm{c}$.

11. Марков В. О. Нові підходи у комплексному лікуванні цукрового діабету / В. О. Марков // Одеськ. мед. журнал. - 2002. - №2. - С. 60-63. підшлунковій залозі.

Отримані дані вказують на позитивний терапевтичний вплив стовбурових клітин, що в подальшому дасть змогу використовувати їх у клінічній практиці під час лікування цукрового діабету.

12. Меркулов Г. А. Курс патологогистологической техники / Г. А. Меркулов. - Л. : Медицина, 1961. -423 с.

13. Морозова K. Н. Электронная микроскопия в цитологических исследованиях: методическое пособие / Новосибирск : Новосиб. гос. ун-т., 2013. -85 c.

14. Скибо Ю. В., Абрамова 3. И. Методы исследования программируемой клеточной гибели : Учебно-методическое пособие для магистров по курсу «Теория апоптоза» / Ю. В. Скибо, 3. И. Абрамова. - Казань : ФГАОУ ВПО КФУ, 2011. $-61 \mathrm{c}$.

15. Шахбазиди Г. Сахарный диабет. Диагностика, классификация, критерии компенсации / Г. Шахбазиди, Д. Д. Дунаева, Г. И. Гордеева // Крымский терапевтический журнал. - 2006. №2. - С. 62-66.

16. Hayek $A$. Cell replacement in type 1 diabetes mellitus / A. Hayek // J. Pediatr. Endocrinol. Metab. -2005. - Vol. 18, Suppl. 1. - P. 1157-1161.

17. Jocelyn H. Histopathologic Techniques / H. Jocelyn, M. D. Bruce-Gregorios. - Philippines : Good Will Bookstore, 1974. - 257 p.

18. The role of capsule composition and biologic responses in the function of transplanted microencapsulated islets of Langerhans / [King A., Andersson A., Berit L. S. et al.] // Transplantation. 2003. - Vol.76, №2. - P. 275-279.

19. $W u$ G. D. Migration of mesenchymal stem cells to heart allografts during chronic rejection / [Wu G. D., Nolta G. A., Jin Y.S. et.al.] // Transplantation, 2003. - Mar. 15. - 75 (5). P. 679-685.

20. Wynn R.F. A small proportion of mesenchymal stem cells strongly expresses functionally active CXCR4 receptor capable of promoting migration to bone marrow / R. F. Wynn, C. A. Hart, C. Corradi-Perini // Blood 2004 Nov.1. 104 (9). - P. 2643-2645. 